\title{
Challenges of wildlife with therapeutic properties in Nigeria; a conservation perspective
}

\begin{abstract}
Several species of biodiversity are found in Nigerian ecosystem. Some of the species are of global significance. Wildlife including mammals, amphibians, avian fauna, reptiles etc has been wildly studied probably due to their food and medicinal potentials. In Nigeria the practice of Zootherapy exists among traditional medicine practitioners, though some people considered it as superstition. Several parts of some wildlife have been reported to have medicinal potentials against several human diseases. But in the recent time the wildlife species are under threat due to habitats destruction, excessive exploitation, quest for bush meat. These have made some of the wildlife found in Nigerian forest to be rear. This is also affecting the practice of Zootherapy because of the increase in prices of animals parts especially the rear species. The study concludes by suggesting the need to manage the environmental factors leading to loss of biodiversity in the forest by the appropriate agencies. The implementation of several international conventions and legislations protecting biodiversity in which Nigeria is part of, as well as national and traditional/customary convention protecting certain biodiversity needs to be enforced.
\end{abstract}

Keywords: biodiversity, conservation, diseases, ecology, environmental degradation, zootherapy
Volume 3 Issue 4 - 2018

\author{
Sylvester Chibueze Izah, Enetimi Idah \\ Seiyaboh \\ Department of Biological Sciences, Niger Delta University, \\ Nigeria
}

Correspondence: Sylvester Izah, Niger Delta University, Biological Sciences Department, Faculty of Science, Niger Delta University, Wilberforce Island, Bayelsa State, Nigeria, Tel +23470301-9246-6, Email chivestizah@gmail.com

Received: May 30, 2018 | Published: July 02, 2018

\section{Introduction}

Traditional medicine practice is as old as human history. Magige ${ }^{1}$ is with the opinion that traditional medicine practice using animals and plants as active ingredients is from time immemorial especially in rural areas. Setlalekgomo ${ }^{2}$ also reported that animals play essential role in human life since ancient time. Traditional medicine practice is common in rural areas in many developing countries.

Traditional medicine practitioners typically use ecosystem resources for the treatment of several types of diseases. Plants and animals have been widely employed to these effects. For instance, authors have variously reported that medicinal plants as plant whose different parts (leaves, fruits, flower, roots, stem etc) have pharmacological properties. ${ }^{3-9}$ In addition, several parts of animals are used for the treatment of some disease conditions. The use of plants and animals parts in managing diseases has the tendency to reduce the dependency on modern medicine for certain disease conditions. According to Djagoun et al., ${ }^{10}$ the use of animals with therapeutic potentials has socioeconomic and cultural importance and could lead to reduction in number of populace that patronizes modern medicine.

A large number of world populations rely on plants and animals for the cure and management of several disease conditions. According to World Health Organization, about $80 \%$ of the global population still relies on botanicals and wildlife for medicine. ${ }^{11}$ Typically, studies on the therapeutic potentials of animals is not comparable to that of plants despites its importance in many regions of the world. ${ }^{12}$ Zootherapy (animals with therapeutics properties) has a broad geographical distribution and very deep historical origins in many parts of the world. For instance, Sowed ${ }^{13}$ reported that zootherapy is widely accepted among different nationality in Nigeria. The authors further reported Zootherapy in Nigeria also involves psychological, spiritual or even mystical backgrounds.
Typically, wildlife has been variously exploited as zootherapeutic resources in practically every human culture ${ }^{14}$ especially many regions of Africa. Djagoun et al., ${ }^{10}$ is with the opinion that the use of zootherapeutic resources is an economic diversification strategy developed by indigenous people especially in some African countries such as Benin republic. Many people have considered Zootherapy as superstition, yet many animals have been reported to have pharmacological purposes and have been seen as potential alternative to some drugs. ${ }^{14}$ In the use of zootherapeutical resources, there is the need for transdisciplinary approach to incorporate the various aspects of Zootherapy in a manner in which the frameworks or methods will merge the ecological and social components of the practice. ${ }^{11}$ Hence there is the need for the shift in direction of practice. Alves \& Rosa ${ }^{11}$ opined that integration of the cultural and biological aspects of Zootherapy to involve conservation of species, cooperative management, and sustainability of the practice.

Nigeria is rich in biodiversity especially in the Niger Delta region. Authors have variously reported that that Niger Delta region is among major hotspot for biodiversity in the world with many endemic species found in the area. Generally, many biodiversity in Nigeria is under severe threat due to human activities. ${ }^{15-17}$ There have been an increase in the demand of wild animals especially mammal for utilization by traditional medicine practitioners. ${ }^{18}$ In this regard, several parts of many species of wildlife have been used for as active ingredients for the treatment of several diseases. ${ }^{18-23}$ According to Soewu et al. ${ }^{21}$ the choice of different animal species and their parts could be due to their bioactive ingredients, morpho-physiological properties, behavioural ecology and mythological notions of such animal.

In many regions of the world the role of animals in human health has been reported. ${ }^{18-23}$ For instance, In Serengeti District of Tanzania Magige $^{1}$ reported that Lepus microtis (African savannah hare) blood 
is used for the treatment of diarrhea and stomach ache, while fur and bones are used to cure wounds and burns; Hystrix cristata (Crested Porcupine) spines is used in preventing nose bleeding, treatment of painful breast and increasing appetite, the fat is used in treating chest pain, faecal pellets is used in relieving neck pains and the skin is used in treatment of painful breast; and Procavi acapensis (African rock hyrax) faecal pellets is used in the treatment of convulsions. In a review study, Alves ${ }^{20}$ reported that about 290 species of animal are used by traditional medicine practice in Brazil. Alves et al., ${ }^{12}$ reported that 51 animal species are used for the treatment of 68 different diseases in a rural community in the semi-arid region of Caatinga Biome. Furthermore, previous study by Soewu ${ }^{21}$ has reported the wildlife with ethno zoological practices among the Yorubas of southwestern Nigeria. Soewu \& Ayodele, ${ }^{22}$ Soewu \& Adekanola ${ }^{23}$ reported the knowledge of traditional medicine practitioners on pangolins (Manis sps) in Southwestern Nigeria. Banjo et al. ${ }^{24}$ reported the ethno-zoological role of insects in Ogun state, Nigeria. Hence, this study focused on the challenges of zootherapeutic in Nigeria with regard to their conservation.

\section{Wildlife studies in some areas in Nigeria}

Different studies have reported several wildlife i.e. reptiles, avian fauna, mammals, insects, amphibians in different forest reserves in Nigeria. In the assessment of wildlife species, survey, semistructure questionnaire, direct sighting etc have been employed. For Instance, Ohimain et al., ${ }^{25}$ reported 45 mammals and 78 avian fauna in Wilberforce Island, Bayelsa state. Hamadina et al., ${ }^{26}$ reported 36 mammals, 18 reptiles, 67 avian fauna, in Nun river forest reserve in Bayelsa state. Lameed $^{27}$ reported 47 mammalian, 7 reptilian species in Kwale forest reserve and the Okpai ecosystem Delta state. The author further reported that avian population varying according to location within the forest with 19 species found in villages and farmlands, 49 species found in forest area, and 14 species found in river bank and beaches. In addition, Akani et al., ${ }^{28}$ reported 28 mammals, 31 reptilian and 9 amphibian species in Edumanon Forest Reserve in Bayelsa state. Akani et al., ${ }^{29}$ reported 27 mammals, 34 reptiles and 10 amphibian species in Taylor creek forest reserve in Bayelsa state. Akani et al., ${ }^{30}$ reported 60 reptilian species in the Eastern Niger Delta. Akani et al., ${ }^{31}$ reported 28 species of amphibians in an area affected by oil and gas activities between 1996-2002 in the Niger Delta. Amadi et al., ${ }^{32}$ reported two-spotted civet (Nandinia binotata) in some forest reserves in the Niger Delta region. ${ }^{33}$ Okore et al., ${ }^{34}$ reported several species of termites, crickets, Grasshopper and Praying mantis, Palm weevil/Edible worm, Rhinoceros, Yam beetle, Rice weevil, Bean beetle, Fish/hides beetle, Egg fruit borers, Mopane worm, Bees, House flies, uncertain species of cotton strainer, aphids and locust in some areas in the Niger Delta.

\section{Wildlife with zootherapeutic in Nigeria}

Zootherapy constitutes a vital medicine alternative among many other known therapies practiced worldwide ${ }^{11-14}$ including Brazil, ${ }^{39-42}$ Nigeria. ${ }^{13,18,19,21-23}$ Different parts of domestic and wild animals (viz: hooves, skins, blood, bones, oil, feathers, tusks etc) is an essential ingredients in the management of several diseases. Typically, in several region of Nigeria different species of wildlife have been reported to be used for the treatment of diseases, while some have mythological characteristics. The most commonly reported wildlife includes avian fauna, mammals, reptiles, amphibians. For instance, Mbaya \& Malgwi ${ }^{43}$ reported the presence of 17 and 14 species of mammals and birds respectively from Sambisa Game Reserve using direct sighting, animal signs and activities, information from hunters and survey of bush meat processing and selling areas. The authors further mentioned that some of the species have medicinal properties against certain disease conditions.

Soewu et al., ${ }^{18}$ reported that some wildlife species traded for utilization by traditional medicine practitioners in Ogun State, Nigeria. The authors further listed Tatera valida, Hippotragus equinus, Lemniscomys striatus, Manis tricuspis, Panthera pardus, Crocidiora spp, Dendrohyrax dorsalis, Mastomys natalensis, Colobus spp, Syncerus caffer, Leptailurus serval, Mus minutoides, Arvicanthis niloticus, Civettictis civetta, Cephalophus maxwelli, Tragelaphus scriptus, Erythrocebus patas, Crocuta crocuta, Xerus erythropus, Gorilla gorilla, Herpestes sanguineus, Pan troglodytes, Funisciurus pyrrhopus, Cricetomys gambianus, Felis silvestris, Lophuromys sikapusi, Hystrix cristata, Thryonomys swinderianus, Hybomys trivirgatus. Of these, Leopard (Panthera pardus), Chimpanzee (Pan troglodytes) and Elephant (Loxodonta africana) have been listed under Control of International Trade in Endangered Species (CITES) and Nigerian Decree 11(1985) I, Lion (Panthera leo), White bellied Pangolin (Manis tricuspis), Colobus monkey (Colobus sp), Patas monkey (Erythrocebus patas), Wild cat (Felis silvestris), Serval (Leptailurus serval) were listed under CITES II, and Lion (Panthera leo), White bellied Pangolin (Manis tricuspis), Colobus monkey (Colobus sp), Wild cat (Felis silvestris), Serval (Leptailurus serval) under Decree 11(1985) 1, while Patas monkey (Erythrocebus patas), Spotted hyena (Crocutta crocutta), Slender mongoose (Herpestes sanguineus) and Roan antelope (Hippotragus equinus) under Decree 11(1985) $2 .^{18}$

Saidu \& Buij ${ }^{44}$ reported that 113 traditional medicinal traders in 39 markets within eight states in northern Nigeria and $78 \%$ had feathers of vultures on display in their stalls, $11 \%$ had vulture heads and $4.4 \%$ had the whole vultures; and $40 \%$ of traders sold the vultures for spiritual healing and $25 \%$ sold vultures for consumption. The authors further reported that hooded Vulture (Necrosyrtes monachus) is the most common species traded in the area. Ajagun \& Anyaku ${ }^{45}$ reported that 55 animal species including 2 arthropods and amphibians, 1 molluscs, 9 reptiles, 1 avian fauna and 28 mammals are used by traditional medicine practitioners by the indigenous people of Ogbomoso, Oyo State. Of the 55 species reported 21 are listed as threatened in the CITES listings, while 15, 2, 2,6 and 18 are endangered, critically endangered, vulnerable, near threatened respectively. ${ }^{45}$

Weliange et al., ${ }^{46}$ reported the occurrence of 21 species of birds in Omi-aro and Labaka villages, Kwara State, and 21, 4, 6 and 10 species have food properties, magico-medicinal uses, feathers are only used as ornamental, and objects for superstitions respectively. Setlalekgomo ${ }^{2}$ reported that different body parts (blood and scale) of pangolins are used for the treatment of several diseases including cracked heels, epistaxis, hypertension and psoriasis in Lentsweletau area of Botswana. The authors further reported that tail, head, paws, scale and whole body are used for charms preparation. Osunsina et al., ${ }^{47}$ reported the presence of 40 species of wildlife belonging to 3 classes, 14 orders, 27 families in villages around some Nigeria National Parks. The authors reported that most of the animal parts are used for the treatment of several human diseases including pile, cough, epilepsy, hemorrhage, rheumatism and cancer.

Soewu ${ }^{21}$ reported that in Ogun state, 55 species of animals are used by traditional medicine practitioner and 21 of them are listed as 
threatened in Nigeria's Endangered Species (Control of International Trade and Traffic) Decree 11 of 1985 and CITES. The authors listed the animals species to include 2 amphibian species including Toad (Bufo regularis) and Frog (Rana temporaria); 1 Molluscs including African giant snail (Archachatina marginata); 8 Reptilian species including Cobra (Naja spp ), Tortoise (Kinixys spp), Nile monitor (Varanus niloticus), African python (Python sebae), Senegal chameleon (Chamaeleo senegalensis), Nile crocodile (Crocodylus niloticus), Gabon viper (Bitis gabonica) and Mamba (Dendroaspis spp); 14 Avian species including Red eye dove (Streptoprelia semitorquata), Blue-eared glossy starling (Lamprotornis chalybaus), Pied crow (Corvus albus), Little grebe (Tachybaptus ruficollis), Carmine bee-eater (Merops nubicus), Double-spurred francolin (Francolinus bicalcaratus), Black kite (Milvus migrans), Harrier hawk (Polyboroides radiates), African grey parrot (Psittacus erithacus), Hooded vulture (Necrosyrtes monachus), Cattle egret (Ardeola ibis), Indian peafowl (Pavo cristatus), Barn owl (Tyto alba), Spotted eagle owl (Bubo africanus), 19 Mammalian species including Straw-coloured fruit bat (Eidolon helvum), Savanna gerbil (Tatera valida), Roan antelope (Hippotragus equine), Spotted grass mouse (Lemniscomys striatus), White-bellied pangolin (Manis tricuspis), Leopard (Panthera pardus), Shrew (Crocidiora spp), Beecrot's hyrax (Dendrohyrax dorsalis), Multimamate rat (Mastomys natalensis), Colobus monkey (Colobus spp), African buffalo (Syncerus caffer), Serval (Leptailurus serval), Pigmy mouse (Mus minutoides), Nile rat (Arvicanthis niloticus), African civet (Civettictis civetta), Maxwell's duiker (Cephalophus maxwelli), Bushbuck (Tragelaphus scriptus), Patas monkey (Erythrocebus patas), and Spotted hyena (Crocuta crocuta).

Some of these animals have been implicated to have zootherapeutic and mythological characteristics. For instance, Soewu ${ }^{21}$ reported that animals with trado-medicinal properties in Ogun state to include bones of Elephant, Roan antelope, Lion; fats and bones of Python, whole tail bones of Crocodile, fore and hind limbs of Slender mongoose (Rheumatism), bones of Gorilla, Elephant, Roan antelope and skull of Colobus monkey and Chimpanzee (bone fracture); Carcass of Serval, whole of Nile monitor, whole of Vulture and Chameleon, and head of Leopard (Protection against evil influences/manipulation); skin of Leopard, Gall bladder and liver of Python, tail of Chameleon, scale of Crocodile, skin and claws of Spotted hyena, Skin, bones and claws of Serval (Snake poison); placenta of Chimpanzee and Colobus monkey, internal organs of female Pangolin and wild cat, eggs of Parrot, whole vulture (Fertility in women); male organs of Gorilla, wild cat, whole male of Pangolin, Crocodile and serval (aphrodisiacs/ potency for men); left arm of Chimpanzee and Gorilla, head of Python and leopard, whole of Parrot and Owl, vulture (Appeasing witches); head of Serval, Chimpanzee, whole of Python, owl and Pangolin, head and fore hind arms of Patas monkey (fortune rousers); fore limbs of Colobus monkey, head of Patas monkey, Python and Crocodile, whole of Monitor lizard and owl (Prevention of accidents); and whole of Vulture, owl and Pangolin, head of Python, Slender mongoose, fore arm of Colobus and Patas monkey (Seeking marital partner). Oduntan et al., ${ }^{48}$ reported that hide of Leopard (as anti-snake venom), anus of Civet cat and whole of Squirrel (anti- convulsions), Mongoose (boosting of immune system), penis of Gorilla, intestine of Crocodile and hair of squirell (anti-poison drugs preparation), skull of Patas Monkey (treatment of whooping cough), intestine of Porcupine (treatment for stomach ache), head of Pangoline (control of bleeding preparations), bone of Aadvark (back ache treatment) and legs of Warthogs (prevention of lameness), intestine of Puff adder (prevention of adultery in women), bone of python (treatment of backache and spinal cord impairment), fat of python (treatment of rheumatism, broken bones and joints), head of python (treatment of lunatism) intestine of Grey duikers (treatment of stomach ache), bone of Buffalo (anti- vomiting), head of Bushbuck (management of leprosy), the skin and placenta of Bushbuck (management of sleeping sickness), whole tortoise (treatment of chest pains), head of monkeys (management of mental disorder), carcass of Snail (Asthma), Whole Chamelion (cure of dizziness), horn of Duicker (resuscitation), head of black cobra (to cause fear in opponent), whole crickets (retentive memory).

\section{Challenges of zootherapeutic resources in Nigeria}

According to Soewu ${ }^{13}$ the use of wildlife does not have consideration for their sustainability with regard to conservation status of the species. Many animals found in some areas in Nigeria within the last 5 decades ago are now rare, some are threatened and endangered. In the zootherapeutics practice, consideration is not frequently put into place with regard to their population trend. As such many rear, threatened and endangered wildlife species are being used extensively in zootherapeutic practices. ${ }^{13}$ Some of the challenges confronting the conservation of these useful animals including bush burning, bust meat, habitat destruction, climate change among others.

\section{Trading of wildlife as bush meat}

In many African countries including Nigeria, bushmeat are widely traded along the express way ${ }^{25}$ and open markets. ${ }^{15-16}$ The exploitation of wildlife as bushmeat is wide known in many regions of Africa, but its utilization as medicine is not widely known ${ }^{10}$ compared to plant. ${ }^{12}$ Akani et al., ${ }^{49}$ reported 21 mammalian species being sold in market in Yenagoa Bayelsa state between 2010-2014. Akani et al., ${ }^{50}$ reported several mammals in bush meat markets in some locations in Rivers, Bayelsa, Delta and Edo states. Most of these bush meat are mainly consumed as diet. Ohimain et al., ${ }^{25}$ have reported that several species of wildlife especially monkeys are traded along the Amassoma-Yenagoa express way in Wilberforce Island for food and other downstream uses.

\section{Habitat destruction}

Developmental projects including to urbanization, intensive agricultural practices and industrialization are the major factors leading to deforestation. ${ }^{15-17}$ Habitats destruction also includes the use of forest resources for developmental works such as use of timber for plank production. Typically, most biodiversity are found in the forest. Due to habitat destruction, several forests were gazatted in different locations in Nigeria covering the major ecological zones such as mangroves forest, lowland rainforest, freshwater forest and savannah. Despites the legislation and conventions protecting wildlife in which Nigeria is part of, the size of protected areas is on the decline trend. ${ }^{15,17,51}$ Hence the destruction of habitat will expose the wildlife to attack by humans. These could also lead to migration as well.

\section{Excessive exploitation}

Most region of Nigeria such as the Niger Delta is a hub of biodiversity including endemic species. Most of the endemic species have been implicated to have zootheuraptic properties. Hunting practices are major route of exploiting wildlife in most rural areas in 
Nigeria. The wildlife which is a primary source of protein to human, and are hunted for several reasons including use of different part for traditional medicine purposes, sale (source of income), avoid attack on crops in agricultural fields. According to Izah et al., ${ }^{16}$ hunting of wildlife is a major factor enhancing the decrease of species composition and abundance in many Nigeria forest reserve.

\section{Bush Burning}

Bush burning is an important factor leading to decline in wildlife is several part of Nigeria. Typically, fire is essential in agricultural purposes. In many rural areas in Nigeria fire is used during land preparation for agricultural purpose. As such this type of fire is often controlled and meant for specified area. However, fire becomes wild when it is not controlled. Several factors have been reported to cause wild fire in the Niger Delta region. ${ }^{17}$ Besides the destruction of habitats, it also cause public disturbance due to varying concentration and content of the emissions. Bush burning affects biodiversity killing both the young and adult especially slow running ones. Instances of wildlife such as snails (molluscs), rabbits, porcupine, glasscutter (mammals) some species of snakes (reptiles), toad (amphibians) found in burnt forest exist. Some of this wildlife has been implicated to have therapeutic potentials.

\section{Climate change}

According to Hamid et al., ${ }^{52}$ Jamal et al., ${ }^{53}$ Izah et al., ${ }^{16}$ bush burning enhance desert encroachment and contribute to global warming through emissions of pollutant gases. Obayelu, ${ }^{54}$ Izah et al., ${ }^{16}$ also reported the links between land degradation, loss of biodiversity and climate change. The ecosystem has the tendency to support lives. As such any activities that could cause adverse impact of the ecosystem could directly or indirectly affect the distribution and composition of biodiversity is such environment. Varying environmental conditions are known to affect biodiversity. For instance, Staudinger et al., ${ }^{55}$ Izah et al., ${ }^{16}$ reported that high atmospheric carbon dioxide and temperature, flooding, changes in hydrological regimes, sea rise could cause a shifts in phenology of species and population structure and composition, mortality, damage of behavioral response and loss of habitats. Hence, climate change could be indirectly affecting population of composition of wildlife with therapeutic properties.

\section{Conclusion and the way forward}

Like plants, animals (mammals, reptiles, amphibians, avian fauna etc) have therapeutic properties. In Nigeria, different parts (head skull, hooves, skins, blood, bones, oil, feathers, tusks, limbs etc) of some animals are used for the treatment of several diseases and some also have mythological potentials. Several species of biodiversity are found in Nigeria including species of global significance. The level of exploitation of these animals is high especially within the last 30-50 years. As such some of species that used to be common are now rear in some part of Nigeria, while some few species have not been cited within the last decades. Due to these, the role of animals could be hindered if some of the animals' parts that are used for the treatment of specific type of disease condition could not be found again. Therefore there the need for sustainable practices to ensure that zootherapeutic potentials in Nigeria do now fade away with time. In recent times the price of these animal parts has increased especially the rear species. This could be due to the difficulty in obtaining some of them. The environmental factors enhancing the loss of biodiversity should be checkmated by appropriate agencies. Also there is the need to contextualize the human and nature connection within its cultural dimension for sustainable practice of Zootherapy.

\section{Acknowledgements}

None.

\section{Conflicts of interest}

Author declares that there is no conflict of interest.

\section{References}

1. Magige FJ. Traditional medicinal uses of small mammal products: a case study of the African Savannah hares, Crested Porcupines and Rock Hyraxes in Serengeti District, Tanzania. Tanz J Sci. 2015;41:62-71.

2. Setlalekgomo MR. Ethnozoological Survey of the Indigenous Knowledge on the Use of Pangolins (Manis Sps) in Traditional Medicine in Lentsweletau Extended Area in Botswana. J Anim Sci Adv. 2015;4(6):883890

3. Izah SC, Uhunmwangho E, Eledo BO. Medicinal potentials of Buchholzia coriacea (wonderful kola). Medicinal Plant Research. 2018;8(5):27-43.

4. Izah SC, Zige DV, Alagoa KJ, et al. Antibacterial Efficacy of Aqueous Extract of Myristica fragrans (Common Nutmeg). EC Pharmacology and Toxicology. 2018;6(4):291-295.

5. Izah SC, Uhunmwangho EJ, Etim NG. Antibacterial and synergistic potency of methanolic leaf extracts of Vernonia amygdalina L and Ocimum gratissimum L. Journal of Basic Pharmacology and Toxicology. 2018;2(1):8-12.

6. Izah SC, Aseibai ER. Antibacterial and Synergistic Activities of Methanolic Leaf Extract of Lemon Grass (Cymbopogon citratus) and Rhizome of Ginger (Zingiber officinale) against Escherichia coli, Staphylococcus aureus and Bacillus subtilis. Acta Scientific Microbiology. 2018;1(6):2630 .

7. Kigigha LT, Selekere RE, Izah SC. Antibacterial and synergistic efficacy of acetone extracts of Garcinia kola (Bitter kola) and Buchholzia coriacea (Wonderful kola). Journal of Basic Pharmacology and Toxicology. 2018;2(1):13-17.

8. Kigigha LT, Biye SE, Izah SC. Phytochemical and antibacterial activities of Musanga cecropioides tissues against Escherichia coli, Pseudomonas aeruginosa Staphylococcus aureus, Proteus and Bacillus species. International Journal of Applied Research and Technology. 2016;5(1):100-107.

9. Kigigha, LT, Izah SC. et al. Activities of Aframomum melegueta seed against Escherichia coli, Staphylococcus aureus and Bacillus species. Point Journal of Botany and Microbiology Research. 2015;1(2):23-29.

10. Djagoun CAMS, Akpona HA, Mensah GA, et al. Wild Mammals Trade for Zootherapeutic and Mythic Purposes in Benin (West Africa): Capitalizing Species Involved, Provision Sources, and Implications or Conservation. Animals in Traditional Folk Medicine; 2012.

11. Alves RRN, Rosa IL. Why study the use of animal products in traditional medicines? Journal of Ethnobiology and Ethnomedicine. 2005;1(5).

12. Alves RRN, Barbosa JAA, Santos SLDX, et al. Animal-Based Remedies as Complementary Medicines in the Semi-Arid Region of Northeastern Brazil. Evidence-Based Complementary and Alternative Medicine. 2011.

13. Soewu DA. Zootherapy and Biodiversity Conservation in Nigeria. Animals in Traditional Folk Medicine. 2012; 347-365.

14. Costa-Neto EM. Animal-based medicines: biological prospection and the sustainable use of zootherapeutic resources. Anais da Academia Brasileira de Ciências. 2015;77(1):33-43.

15. Izah SC, Seiyaboh EI. Changes in the protected areas of Bayelsa state, Nigeria. International Journal of Molecular Evolution and Biodiversity. 2018;8(1):1-11. 
16. Izah SC, Aigberua AO, Nduka JO. Factors affecting the population trend of biodiversity in the Niger Delta region of Nigeria. IJAWB. 2018;3(3):206-214.

17. Izah SC, Angaye $\mathrm{CN}$, Aigberua AO, et al. Uncontrolled bush burning in the Niger Delta region of Nigeria: potential causes and impacts on biodiversity. International Journal of Molecular Ecology and Conservation. 2017;7(1):1-15.

18. Soewu DA, Bakare OK, Ayodele. Trade in Wild Mammalian Species for Traditional Medicine in Ogun State, Nigeria. Global Journal of Medical research. 2012;12(3):6-21.

19. Ajagun EJ, Anyaku CE, Afolayan MP. A survey of the Traditional Medical and Non-medical Uses of Animals Species and Parts of the Indigenous people of Ogbomoso, Oyo State. International Journal of Herbal Medicine. 2017;5(3):26-32.

20. Alves RRN. Animal-based remedies as complementary medicine in Brazil. Forschende Komplementarmedizin. 2008;15(4):226-227.

21. Soewu DA. Wild animals in ethnozoological practices among the Yorubas of southwestern Nigeria and the implications for biodiversity conservation. African Journal of Agricultural Research. 2008;3(6):421-427.

22. Soewu DA, Ayodele IA. Utilisation of Pangolin (Manis sps) in traditional Yorubic medicine in Ijebu pronvince, Ogun State, Nigeria. $J$ Ethnobiol Ethnomed. 2009;5(39):1-11.

23. Soewu DA, Adekanola TA. Traditional-medical knowledge and perception of pangolins (Manis sps) among the Awori people, Southwestern Nigeria. J Ethnobiol Ethnomed. 2011;7(25):1-11.

24. Banjo AD, Lawal OA, Owolana OA, et al. An Ethno-zoological survey of insect and their allies among the Remos (Ogun State). Afr J Indigenous Knowl Syst. 2002;2(1):61-67.

25. Ohimain EI, Izah SC, Otobotekere D. Selective impacts of the 2012 water floods on the vegetation and wildlife of Wilberforce Island, Nigeria. International Journal of Environmental Monitoring Analysis. 2014;(2):73-85.

26. Hamadina MK, Otobotekere D, Anyanwu DI. Impact assessment and biodiversity considerations in Nigeria: a case study of Niger Delta University campus project on wildlife in Nun River forest reserve. Management of Environmental Quality: An International Journal. 2007;18(2):179-197.

27. Lameed GA. Potential impact on biodiversity in Kwale's forest reserve by power plant establishments. African Journal of Food, Agriculture, Nutrition and Development. 2009;9(9):1878-1900.

28. Akani GC, Aifesehi PEE, Petrozzi F, et al. Preliminary surveys of the terrestrial vertebrate fauna (mammals, reptiles, and amphibians) of the Edumanon Forest Reserve, Nigeria. Tropical Zoology. 2014;27(3):63-72.

29. Akani GC, Aifesehi PEE. Diversity of terrestrial vertebrates in Taylor creek forest reserve, an area of high environmental value in the River Niger Delta (Bayelsa State, Nigeria). Vie et milieu-Life and environment. 2014;(64):59-68.

30. Akani GC, Luiselli L, Politano E. Ecological and conservation considerations on the reptile fauna of the eastern Niger Delta (Nigeria). Herpetozoa. 1999;11(3):141-153.

31. Akani GC, Politano E, Luiselli L. Amphibians recorded in forest swamp areas of the River Niger Delta (southeastern Nigeria), and the effects of habitat alteration from oil industry development on species richness and diversity. Applied Herpetology. 2004;2(1):1-22.

32. Amadi N, Akani GC, Micheloni P, et al. Distribution, habitat ecology and conservation status of the Two-spotted Palm Civet Nandinia binotata (Carnivora, Nandiniidae) in south-eastern Nigeria. Small Carnivore Conservation. 2016;(52):24-38.
33. Okore O, Avaoja D, Nwana I. Edible Insects of the Niger Delta Area in Nigeria. Journal of Natural Sciences Research. 2014;4(5):1-9.

34. Alves RRN. Fauna used in popular medicine in Northeast Brazil. Journal of Ethnobiology and Ethnomedicine. 2009;5(1).

35. Alves RRRN, Oliveira TPR, Rosa IL. Wild Animals Used as Food Medicine in Brazil. Evidence-Based Complementary and Alternative Medicine. 2013.

36. Alves RRN, Alves HN. The faunal drugstore: Animal-based remedies used in traditional medicines in Latin America. Journal of Ethnobiology and Ethnomedicine. 2011;7(9).

37. Alves RRN, Rosa IL. From cnidarians to mammals: the use of animals as remedies in fishing communities in NE Brazil. J Ethnopharmacol. 2006;(107):259-276.

38. Alves RRN, Rosa IL. Biodiversity, traditional medicine and public health: where do they meet? J Ethnobiol Ethnomed. 2007;(3):1-9.

39. Alves RRN, Rosa IL. Zootherapeutic practices among fishing communities in North and Northeast Brazil: a comparison. J Ethnopharmacol. 2007;111(1):82-103.

40. Alves RRN, Barboza RRD, Silva Souto WMS. A Global overview of canids used in traditional medicines. Biodiversity and Conservation. 2010;19(6):1513-1522.

41. Alves RRN, Léo Neto NA, Brooks SE, et al. Commercialization of animal-derived remedies as complementary medicine in the semi-arid region of Northeastern Brazil. J Ethnopharmacol. 2009;124(3):600-608.

42. Alves RRN, Vieira WLS, Santana GG. Reptiles used in traditional folk medicine: conservation implications. Biodiversity and Conservation. 2008; 17:2037-2049.

43. Mbaya YP, Malgwi H. Species list and status of mammals and birds in Sambisa game reserve, Borno state, Nigeria. Journal of Research in Forestry, Wildlife and Environment. 2010;2(1):135-140.

44. Saidu Y, Buij R. Traditional medicine trade in vulture parts in northern Nigeria. Vulture News. 2013;65:4-14.

45. Ajagun JE, Anyaku EC. Conservation Status of Animal Species Used by Indigenous Traditional Medicine Practitioners in Ogbomoso, Oyo State. Journal of Complementary and Alternative Medical Research. 2007;3(4):1-8.

46. Weliange WS, Kolawole RA, Prasannajith NS, et al. Ethno-ornithological knowledge and uses of birds in Omi-aro and Labaka villages, Kwara State, Nigeria. Malimbus. 2015;37:31-54.

47. Osunsina OO, Inah EI, Onadeko SA, et al. Use of wild animals as alternative therapy in support zone village around some Nigeria National parks. Forests and Forest Products Journal. 2012;5:7-18.

48. Oduntan OO, Akinyemi A, Ojo O, et al. Survey of Wild Animals Used in Zoo-therapy at Ibadan, Oyo State, Nigeria. Intl J of Molecular Zoology. 2012;2(9):70-73.

49. Akani GC, Amadi N, Eniang EA, et al. Are mammal communities occurring at a regional scale reliably represented in "hub" bushmeat markets? A case study with Bayelsa State (Niger Delta, Nigeria). Folia Zoology. 2015;64(1):79-86.

50. Akani GC, Petrozzi F, Ebere N, et al. Correlates of indigenous hunting techniques with wildlife trade in bushmeat markets of the Niger Delta (Nigeria). Vie et milieu-Life and Environment. 2015;65(3):169-174.

51. Ayanlade A. Remote Sensing of Environmental Change in the Niger Delta, Nigeria. King's College London, University of London; 2014.

52. Hamid AA, Usman LA, Elaigwu SE, et al. Environmental and health risk of bush burning. Advances in Environmental Biology. 2010;4(2):241-249. 
53. Jamala GY, Boni PG, Abraham P, et al. Evaluation of environmental and vulnerability impact of bush burning in southern guinea savanna of Adamawa state, Nigeria. American Journal of Experimental Agriculture. 2012; 2(3):359-369.

54. Obayelu AE. Assessment of Land Use Dynamics and the Status of Biodiversity Exploitation and Preservation in Nigeria. Journal for the Advancement of Developing Economies. 2014;3(3):37-54.
55. Staudinger MD, Carter SL, Cross MS, et al. Biodiversity in a changing climate: a synthesis of current and projected trends in the US. Frontier of Ecology and Environment. 2013;11(9):465-473. 